\title{
The career competencies of self-initiated and assigned expatriates: assessing the development of career capital over time
}

Article

Accepted Version

Dickmann, M., Suutari, V., Brewster, C., Mäkelä, L., Tanskanen, J. and Tornikoski, C. (2018) The career competencies of self-initiated and assigned expatriates:

assessing the development of career capital over time. The International Journal of Human Resource Management, 29 (16). pp. 2353-2371. ISSN 1466-4399 doi:

https://doi.org/10.1080/09585192.2016.1172657 Available at https://centaur.reading.ac.uk/65645/

It is advisable to refer to the publisher's version if you intend to cite from the work. See Guidance on citing.

To link to this article DOI: http://dx.doi.org/10.1080/09585192.2016.1172657

Publisher: Routledge

All outputs in CentAUR are protected by Intellectual Property Rights law, including copyright law. Copyright and IPR is retained by the creators or other copyright holders. Terms and conditions for use of this material are defined in the End User Agreement. 


\section{CentAUR}

Central Archive at the University of Reading

Reading's research outputs online 


\title{
The Career Competencies of Self-Initiated and Assigned Expatriates: Assessing the Development of Career Capital over Time
}

\begin{abstract}
Building on a modern careers approach, we assess the effects of working abroad on individuals' career capital. Given the dearth of longitudinal studies, we return to a sample of economics graduates in Finland eight years later. We measure changes in three dimensions of career capital; 'knowing how', 'knowing whom', 'knowing why' and find that company assigned expatriates learn more than self-initiated expatriates. All three career capital areas benefit from international experience and all are increasingly valued over time. Based on our findings we conclude that a dynamic notion of career capital acquisition and use is needed. Managerial implications include the need for a wider view of talent management for international businesses.
\end{abstract}

\section{Keywords:}

Expatriation; self-initiated expatriation; international careers; career capital; longitudinal studies 


\section{The Career Competencies of Self-Initiated and Assigned Expatriates: Assessing the Development of Career Capital over Time}

\section{Introduction}

Interest in global mobility is high and much effort is being devoted to improving the understanding of international careers (Shaffer et al., 2012). In the literature on long-term expatriation two major types of assignment have been identified; company assigned expatriates (AEs) and self-initiated expatriates (SIEs). The focus of nearly all research in the twentieth century was on company assigned expatriates and research on this group continues (Stahl, Miller \& Tung, 2002; Hippler, 2009; Peltokorpi \& Froese, 2009). An emerging research stream in the twenty-first century has been concerned with self-initiated expatriates (Dorsch, Suutari \& Brewster, 2013; Richardson \& Mallon, 2005; Suutari \& Brewster 2000; Tharenou, 2003) and recently two edited books (Andresen, Al Ariss, \& Walther, 2013; Vaiman \& Haslberger, 2013) have reinforced the interest.

It is clear that the two populations are conceptually distinct (AEs are sent by their employer on expatriate terms and conditions, SIEs are not). While some of the insights are still emergent (especially those in relation to SIEs), differences have been identified in a range of areas. SIEs are seen to be more proactive in seeking work abroad and have different demographics in terms of gender, age and educational level (Doherty, 2013; Suutari \& Brewster, 2000; Tharenou \& Caulfield, 2010). In addition, while it is clear that some SIEs occupy high organizational positions, on average SIEs tend to be lower in the organizational hierarchy (Cerdin, 2013; Doherty, Dickmann and Mills, 2011; Jokinen, Brewster \& Suutari, 2008; Peltokorpi \& Froese, 2009) and have a longer foreign stay (Doherty \& Dickmann, 2013; Tharenou, 2010). Data shows that motivational drivers of SIEs are different to those of AEs (Carr, Inkson \& Thorn, 2005; Oberholster et al., 2013). Authors frequently focus on one 
population and argue that some factors are more or less pronounced in that sample, as is the case with SIEs' supposedly greater appetite for accepting risks (Richardson \& Mallon, 2005).

The literature on the differences between AEs and SIEs suffers from serious methodological problems. While there have been some studies directly comparing the two populations (Suutari \& Brewster, 2000; Doherty, Dickmann \& Mills, 2011), limited work has contrasted their careers systematically. Instead, most work has been devoted to investigating either AEs or SIEs but not comparing them within the same study. In addition, studies have normally not been able to calculate base numbers and have no way of assessing representativeness. In this study we contribute to the literature by comparing those two populations of expatriates using samples representative for Finnish economics and business graduates.

Individuals tend to be seen in extant research as responsible for their own careers. Boundaryless as well as protean career perspectives are common in modern careers research (Sullivan \& Arthur, 2006; Hall, 1996). The boundaryless career framework, where the individual career is seen as de-coupled from their current organization (Arthur \& Rousseau, 1996), is now prevalent in global career studies (Shaffer et al., 2012). The protean career (Hall, 1996) emphasizes self-management and values (Briscoe \& Hall, 2006).

This study uses the intelligent careers (IC) concept rooted in this literature (Haslberger \& Brewster, 2009). The IC concept consists of three interlinked and mutually reinforcing career capital areas (DeFillippi \& Arthur, 1994). The IC concept is particularly suited to exploring global careers as it incorporates protean ideas through its identity perspective, a competency perspective useful within the analysis of the context of individual careers and a social capital perspective (Mäkelä, Björkman \& Ehrnrooth, 2009; Parker, Khapova \& Arthur, 2009). Possibly for these reasons, the IC concept has been extensively used in global careers research (Shaffer et al., 2012). 
Many authors have argued for the positive career capital impact of the work competencies individuals acquire either through self-initiated or company-sponsored assignments (Scullion et al., 2010; Jokinen et al., 2008). However, it is far from clear whether all assignees benefit. With respect to networks, for example, some studies have argued that AEs suffered detrimental home-country network effects (Dickmann \& Doherty, 2008; Dickmann \& Harris, 2005). Examining motivations and identity, studies indicate that SIEs may suffer negative effects including uncertainty during working abroad and high degrees of risk (Richardson, 2006). Other studies show potentially detrimental impacts on the long-term careers of SIEs and their attitudes to their work both abroad and upon return (Andresen et al., 2013; Al Ariss \& Syed, 2011; Richardson and Mallon, 2005). With respect to these 'darker sides' of international careers more evidence comparing SIEs and AEs systematically is necessary to explore the career capital effects of foreign sojourns.

There have been repeated calls for longitudinal research in careers (Gunz and Peiperl, 2007), even with respect to the intelligent career (Parker, Khapova \& Arthur, 2009). In a recent review article Shaffer et al., (2012) call for more research on the consequences of global career choices. How do AEs and SIEs view the career capital impact of their international work once back in their home country? Was their career capital increased and, if so, is that increase valued over time?

This paper attempts to initiate the process of filling the various gaps outlined above. First, it employs a systematic approach to compare SIEs and AEs in the same study. Second, it investigates all three forms of career capital to explore the impact of international work. Third, it uses longitudinal data to make an empirical contribution to the global careers and international mobility literature by explicating IC developments over time. Fourth, this study allows us to contribute to the academic literature by expanding the theoretical argument of Lamb \& Sutherland (2010) that career capital concepts are based on transferability, 
maximization and self-reinforcing assumptions, a process that needs an explicit temporal dimension. In addition, the data allows us to postulate that the three career capital areas are substantially different with respect to quality considerations.

The paper takes the following form. Using the literature, we outline key differences between SIEs and AEs. We briefly present the IC concept and summarize likely differences in the career capital accumulation of SIEs and AEs before we develop hypotheses exploring the differences between SIEs and AEs in terms of career capital accumulation and the effects of career capital over time. We present the methods through which we test our research hypotheses and then the findings with respect to who is benefiting from global careers. We then critically discuss the findings and reflect on the IC concept before developing theoretical and practical conclusions.

\section{Literature Review}

Millions of people live and work outside their country of origin. One strand of the literature explores the differences between various types of individuals working abroad (Doherty et al., 2011; Hippler, 2009; Jokinen et al., 2008) while another investigates their diverse global careers (Scullion et al., 2010; Lazarova \& Cerdin, 2007; Tharenou \& Caulfield, 2010). Amongst the group of long-term expatriates we can distinguish the AEs who are sent by their employing organizations from those who go to another country for work on their own initiative. The first group consists of traditional expatriates, much studied in the literature and normally classified by their employers as 'international assignees' (Tornikoski, Suutari \& Festing, 2014). SIEs are those who 'make their own way' (Suutari \& Brewster, 2000). In most cases they are locally employed and do not receive any 'expatriate package' (Dowling, Festing \& Engle, 2008). We note that boundaries are fungible (expatriates may stay on and 
their contract may become localized, or SIEs may find a job that gives them contractual advantages over local staff). Overall, however, there is evidence of substantial differences between AEs and SIEs in terms of the way they are managed (Doherty \& Dickmann, 2013) and their subjective experiences (Näsholm, 2014).

\section{Differences between AEs and SIEs}

Global staffing changes and a range of diverse forms of international work have been identified by scholars (Collings, Scullion \& Morley, 2007). A recent review (Shaffer et al., 2012: 1286 - 1288, especially Table 1) compared AEs and SIEs, mostly from an organizational perspective. It identified differences with respect to organizational purpose, duration, compensation, repatriation and international human resource management (IHRM) involvement. The purpose of the assignment (Edström \& Galbraith, 1977) was more closely connected with organizational aims for AEs, their compensation arrangements tended to be more beneficial than for SIEs and the IHRM department was more involved. Repatriation was seen as an organizational problem in the career systems of organizations for AEs while it was an individual undertaking for SIEs. Other reviews examine the individual differences which can be segmented into demographic differences, distinct motivational drivers, personality, factors that emerge during the stay abroad - work elements, adjustment and duration (Andresen, Al-Ariss and Walther, 2013). We discuss below the potential impact of these differences on career capital accumulation.

With respect to demographics, there tends to be a higher proportion of females in the SIE population. Surveys show that three-quarters or more of AEs are male (Brookfield Survey, 2014; Dowling, Festing \& Engle, 2008) whereas it appears that about half of the total of SIEs are female (Doherty 2013; Suutari and Brewster, 2000), although this data is taken 
from northern European populations where women may be more mobile. SIE females are also often younger and less likely to be accompanied by their family than AEs (Doherty, Dickmann \& Mills, 2011). Expatriate populations tend to be professional, well-educated individuals and, indeed, 'high qualifications' was part of the definition put forward by Cerdin \& Selmer (2014). While a direct comparison with AEs is not common, most of the research gives the impression that SIEs are also often graduates who seek new challenges and have a high confidence in their ability to succeed in a foreign environment (Cerdin, 2013; Doherty \& Dickmann, 2013; Rodriguez \& Scurry; 2014). SIEs are generally on 'local' or 'local plus' remuneration packages that are often less generous than the contractual specifications of AEs (Dickmann, 2014).

The extant literature indicates that the motivation to live and work abroad is often less 'career and work' oriented amongst SIEs than AEs (Cerdin, 2013; Thorn, 2009). The motivation of SIEs within the humanitarian aid sector was distinct in the sense that their drivers were often particularly strongly oriented to altruism and dedication to a cause (Hudson \& Inkson, 2006: Oberholster et al., 2013), though, we do not know whether this would be different for AEs in that sector. In turn, Doherty, Dickmann and Mills (2011) made a systematic comparison of the drivers of the two different groups. In SIEs the desire for adventure, for seeing the world, their confidence to work and live abroad, a wish for excitement, their family or other social connections as well as a desire to escape from their current way of life/ job, were all significantly different (and more prominent) than for AEs while AEs have a stronger drive to seek professional challenges, skills developments and gain a positive career impact on traditional career considerations.

One of the defining distinctions between SIEs and AEs is their proactivity in seeking work abroad (Andresen et al., 2014; Suutari \& Brewster, 2000). In personality terms therefore, it seems likely that the SIE's openness to foreign experiences is high. They are likely (with 
some exceptions) to get less organizational support. While AEs can, of course, operate in highly risky environments (Van Emmerik \& Euwema, 2009), their job security and ability to return to their home environments is high (Stahl et al., 2009). SIEs face not only more risk through their lack of organizational support, but they can also encounter more insecurity and job instability (Richardson \& Mallon, 2005), having a weaker company attachment than AEs due to their lower embeddedness in and financial support from the organization (Reiche, Kraimer \& Harzing, 2011; Vaiman \& Haslberger, 2013).

Job factors also appear to be distinctive between the two populations. Unlike AEs, SIEs may find a job after arrival (Peltokorpi, 2008), although numbers of SIEs source foreign jobs for themselves while in their home country (Suutari \& Brewster, 2000). SIEs often have lower hierarchical positions in organizations (Jokinen, Brewster \& Suutari, 2008; Doherty et al., 2011) and less challenging tasks (Suutari \& Brewster, 2000) than AEs. Furthermore, SIEs, unlike AEs, often lack social networks and consequently need to build their social capital in their host environment (Farh et al., 2010; Reiche, Kraimer, \& Harzing, 2011) and hence may have more difficulty accessing positions and jobs where such connections are important (Peltokorpi \& Froese, 2009). This exposes SIEs to potential under-employment which may influence their motivation and career (Lee, 2005).

A final set of differences relates to the duration of the stay abroad and adjustment to the host culture. SIEs have more choices of destinations. They may go to locations they find particularly attractive or where they are familiar with the language or culture or which are within easy/inexpensive travel access (Suutari \& Brewster, 2000). Their higher level of agency and personal investment may generate better local adjustment and integration (Peltokorpi, 2008) and, since adjustment takes place over time (Hippler, Brewster \& Haslberger, 2015) and SIEs tend to stay longer than AEs in their foreign location (Doherty, 
Dickmann \& Mills, 2011) the likelihood of their successful adjustment to the host culture increases.

\section{AEs, SIEs and their Intelligent Careers}

These factors will impact expatriates' careers and that is the topic we turn to now. Throughout their career people build and use career capital. The intelligent career concept incorporates the acquisition of competencies through its 'knowing how' career capital (DeFillippi \& Arthur, 1994; Inkson \& Arthur, 2001), relationship and networking aspects, through its 'knowing whom' career capital (Bozkurt \& Mohr, 2011; Parker, Khapova and Arthur, 2009) and protean career aspects, through its 'knowing why' career capital (Kraimer et al., 2012; Kohonen, 2005). Hence the concept is well suited to exploring modern global careers. For this reason several authors investigating global careers (Jokinen, 2010; Jokinen, Brewster, \& Suutari, 2008) have used it in their research.

\section{Knowing How Effects of International Assignments on SIEs and AEs}

Knowing how career capital relates to the skills, knowledge, insights and abilities that individuals possess (DeFillippi \& Arthur, 1994). It may be explicit or tacit (Inkson \& Arthur, 2001; Nonaka \& Takeuchi, 1995). It is beneficial for careers if it relates to job-relevant competencies (Harvey, Novicevic \& Speier, 2000). Much has been written about the value of expatriation as a potential source of development and testing for managers (Gregersen, Morrison \& Black, 1998; Kohonen, 2005; Stahl, Miller \& Tung, 2002). Ideally, the newly acquired competencies should be transferrable to new positions or 'home' to have a positive career effect (Lamb \& Sutherland, 2010). 
Do international assignments affect the knowing how capital of AEs and SIEs differentially? Both AEs (Kraimer, Shaffer \& Bolino, 2009) and SIEs (Doherty, 2013; McNulty, 2013) believe that their knowing how capital benefited from their work abroad. Whether one of these expatriate groups gains more knowing how career capital is unclear. On one side, it can be argued that given the stronger career and work-related motivation of AEs and their, on average, higher status and position it is likely that AEs gain more organizational and business knowledge through their foreign work (Shaffer et al., 2012). On the other side, SIEs' more holistic approach to living abroad, wider motivational patterns and greater willingness for local interaction, means they should be more exposed to their local environment and have more learning opportunities.

In organizational knowing how AEs may gain more career capital. Maximising and utilizing both social and organizational knowing how can be seen as beneficial for individuals (Lamb \& Sutherland, 2010) as both sets of capabilities can be useful in business situations. In a general measurement the differential gains outlined above may result in a balanced overall knowing how score for both AEs and SIEs. Given these counteracting effects of environmental exposure, we hypothesize:

Hla: There will be no significant differences between SIEs and AEs in terms of their overall knowing how career capital acquisition while abroad.

\section{Knowing Whom Effects of International Assignments on SIEs and AEs}

Inkson and Arthur (2001) argued that increased knowing how will have positive effects on knowing whom. Knowing whom career capital consists of relationships that can be beneficial to one's work and career. Individuals with large social networks have greater career opportunity benefits (Burt, 2005; Granovetter, 1974; Lin, 2001). This idea has been 
developed in social network analysis (Casper \& Murray, 2005). Generally, expatriate managers are seen to have more social capital than their non-expatriated peers (Bozkurt \& Mohr, 2011; Mäkelä, 2007).

Expatriates, AEs and SIEs, function as knowledge brokers, transmitters and boundaryspanners (Mäkelä \& Brewster, 2009; Reiche, Harzing \& Kraimer, 2009; Shaffer et al., 2012). During their foreign work, AEs are likely to build more business contacts both at the head office and at their local operating unit (Farh et al., 2010). Given the fact that AEs often hold higher positions abroad than in their home country, the seniority of their host, international and home contacts and networks may improve. However, the 'out of sight, out of mind' syndrome may, to some extent, off-set this and create a threat to the width of their country-oforigin network (Feldman \& Thomas, 1992).

Does this indicate that AEs will gain more useful social capital than SIEs while working abroad? The following four reasons tend to imply that they will, for work purposes at least. First, AEs are significantly more driven by networking considerations than SIEs (Doherty, Dickmann \& Mills, 2011). Second, AEs have worked longer in their organization and know it better than SIEs who start with it as a new employer. Hence they can use previously built and known existing networks of contacts in their home country to build host country networks, they already have a reputation in their firm and can identify and build key contacts more readily (Bozkurt \& Mohr, 2011; Farh et al., 2010; Inkson \& Arthur, 2001). Third, since AEs often have higher positions and status than SIEs abroad they will have wider and more senior professional networks. Fourth, and relatedly, SIEs may be under-employed in comparison to the job role they would hold based on their capabilities in their home country (Peltokorpi \& Froese, 2009) and so less likely to gain abroad the knowing whom career capital that would be relevant and adequate for their career once back in their home country. Lamb and Sutherland (2010) argue that individuals strive to maximize and transfer their career capital. 
There is also a quality aspect to structural and relational networks (Burt, 1997). Better quality networks give advantages to AEs since it is likely that they interact with more central, powerful business actors (Burt, Kilduff \& Tasselli, 2013). This leads us to propose:

H1b: There will be significant differences between AEs and SIEs in terms of their overall knowing whom career capital acquisition while abroad, with AEs gaining more knowing whom capital.

Knowing Why Effects of International Assignments on SIEs and AEs

In most cases having a strong network can have beneficial effects on both knowing how (learning through others) and knowing why. 'Knowing why' addresses the question of what motivates people in their careers. Since it is linked to identity (DeFillippi \& Arthur, 1994), it is related to the self-concept, personal dispositions, values and interests of persons and the energy that individuals invest in their careers (Inkson \& Arthur, 2001; Parker, Khapova \& Arthur, 2009). Like the other aspects of career capital, knowing why is dynamic since identities shift in response to experiences and contextual changes (Ibarra, 2003). Working abroad influences a person's identity (Kohonen, 2005). Thus, their belief in their own potential, their identification with the world of work, their goals and motivational patterns may be affected.

What are the likely trends of knowing why career capital for AEs and SIEs? Knowing why changes are related to the culture shock and adjustment process that expatriates go through (Haslberger \& Brewster, 2009). Jokinen, Brewster and Suutari (2008) found that although there were some differences at the item measure level, overall knowing why increased substantially for both AEs and SIEs with no significant differences between them. However, some indicators point to differential sizes of the knowing why effect for AEs and SIEs. First, 
all three ways of knowing are interrelated so that a positive development in one area positively influences the two others (Inkson and Arthur, 2001). This in itself would mean that the suspected stronger development of knowing whom for AEs should have (more) positive effects on knowing why. Second, other research suggests that SIEs' international experience may create doubts in their minds about their own motivations, capabilities and self-concept in relation to the world of work (Richardson \& Mallon, 2005; Shaffer et al., 2012). Third, SIEs consciously made their own decision to go abroad, whilst AEs may never seriously have considered the option of going abroad before the opportunity arose and often have little time to prepare for the move (Doherty \& Dickmann, 2012). Due to the more limited choice of host country AEs may experience greater emotional adjustment gaps and due to the shorter preparation time they may have a greater cognitive difference to the host country (Haslberger \& Brewster, 2009). Both these differences may result in a larger culture shock which may trigger more substantial knowing why changes. In addition, AEs normally have more organizational support mechanisms that allow them to understand their emotions and cognitive differences better. This leads us to suggest the following hypothesis:

H1c: There will be significant differences between SIEs and AEs in terms of their overall knowing why career capital acquisition while abroad, with AEs gaining more knowing why capital.

\section{The Time Angle}

Few international human resource management researchers have attempted to use longitudinal data to explore dynamic developments (Hippler et al, 2015). Even in the specific area of international mobility, long term studies on the same populations have been relatively neglected (for exceptions see Takeuchi et al., 2005; Ward et al., 1998). 
Assuming that researchers can overcome associated obstacles, repetitive research on the same populations may deliver new insights. The comparison of career capital developments in samples drawn from the same population, at different times along their career, allows us to identify changes in the extent of learning and development. The passage of time will have allowed the expatriates to experience more of their career journey and to be in a better position to assess the value of the career capital they acquired abroad. This instrumentality may be found or noticed through their international insights, capabilities and networks at more senior positions in MNCs.

What kind of career capital developments could be expected after a significant time period? Below, we formulate some hypotheses that relate to the diverse ways of knowing with respect to the passage of time.

The increasing growth of international trade and investment (UNCTAD, 2012) implies an ever-increasing demand for global experiences, insights and capabilities by employers (McDonnell et al., 2010; Mellahi \& Collings, 2010). So it can be expected that employees with international experience may find crucial and useful career leverages in the knowing how capital they developed abroad. In addition, career development theory links the appreciation of learning to the utility and importance of the insights (Sullivan \& Crocitto, 2007). In organizations that are globalizing, international competencies are likely to be viewed as increasingly important, even after repatriation. These developments lead us to propose that:

H2a. Knowing how capital that was acquired abroad will appear more beneficial to AEs and SIEs in the long term than in the short term.

Social networks can be the key to opening or speeding an individual's career as they reach more senior positions on the hierarchical ladder (Seibert, Kraimer, \& Liden, 2001). 
International working experiences often enable expatriates access to higher or senior people in organizations. Consequently, they might build peer networks useful for their career prospects either back in their home country or in another job (Bozkurt \& Mohr, 2011). Parker, Khapova and Arthur, (2009) showed that access to high-ranking, experienced colleagues can have a beneficial impact on and enhance the quality of an individual's work. Being an $\mathrm{AE}$ often provides access to higher-ranking individuals in the organization than was available before the expatriation (Dickmann \& Baruch, 2011; Dowling, Festing \& Engle, 2008). With the passage of time the structural and relational capital may become clearer to repatriates both through work and social situations (Burt, Kilduff \& Tasselli, 2013; Jokinen 2010; Tharenou 2001). And, the higher people climb, the smaller their circle of peers and the greater value is attached to each contact (Burt, 1997). This leads us to suggest:

H2b. Knowing whom capital that was acquired abroad will appear more beneficial to AEs and SIEs in the long term than in the short term.

Research also indicates that although repatriation may be problematic for returnees, they usually consider the changes implied to their career as positive (Jokinen, Brewster \& Suutari, 2008). Previous studies (Hippler, 2009; Stahl, Miller \& Tung, 2002; Stahl et al., 2009) suggest that original drivers to work abroad are either confirmed and reinforced or challenged throughout working experience. Thus, expatriation has been described as revealing experiences leading individuals to become more aware of who they are and what they want in life. As this will apply to both AEs and SIEs we hypothesize that:

H2c. Knowing why capital that was acquired abroad will appear more beneficial to AEs and SIEs in the long term than in the short term.

\section{Methodology}




\section{Samples}

The hypotheses were tested using data collected in 2004 and 2012. Surveys were conducted in co-operation with the Finnish Business School Graduates' Union. Union membership figures in Finland are amongst the highest in the free world, so it is likely that this group would be representative of all Finnish economics and business graduates. The Association was able to identify and approach individuals who were working abroad in 2004. Our data allowed us to follow up respondents who may have left their employer, changed countries or even retired. This enabled us to have representative responses from SIEs, something not found in the usual web-based approaches where base numbers and hence representativeness cannot be checked. In addition we had a directly comparable representative sample of the AEs more typically found by surveys conducted only via employing organizations. So our database was fully representative of AEs and SIEs for 2012, drawn from a fully representative sample of AEs and SIEs in 2004. This gives us a reasonable timeframe to identify changes in the perceived development and utility of career capital acquired abroad.

Exploring career capital perceptions eight years after the first survey raises the issue of memory bias. Research shows that individuals are likely to exaggerate specific attributes about themselves and career capital acquisition (Kirk \& Sereda, 1969; Dobbins, Farh \& Werbel, 1993) and individuals have a positivity bias in that they remember positive events with more details than negative ones (D'Argembeau \& Van der Linden, 2008). However, while individuals exaggerate current performance, they also use exaggerate past performance (Gramzow \& Willard, 2006). The underlying mechanisms in memory distortion were different, and the differences in the size of the bias between current and past memories are unclear. There are indications that the memory of past events associated with career capital acquisition may be more distorted than the memory of current or more recent career capital 
acquisition (Gramzow \& Willard, 2006). However, due to the paucity of available research, memory bias remains a limitation of our study.

The first survey, in 2004, was sent to 688 expatriates and 233 surveys were returned, but several cases were deleted as multiple or incomplete replies thereby giving an effective sample size of 209 (response rate 30.4\%). Approximately half of the respondents $(50.5 \%$ ) identified themselves as AEs. In 2012 the union provided an up-to-date list of the expatriates from the 2004 survey and the survey was sent to a total of 433 active individuals from the original list. 207 surveys were returned and after deleting four incomplete cases 203 cases were accepted (response rate $46.8 \%)^{1}$. A slight majority of the respondents $(55.9 \%)$ were AEs. Demographic information on the respondents is given in Table 1. The 2004 and 2012 samples differed significantly only regarding mean age of the AEs $(2012:+2.87, \mathrm{t}(209)=$ $2.299, p=.023)$. In the 2004 sample SIEs (41.91) were significantly $(+2.80, \mathrm{t}(204)=2.154, p$ $=.032$ ) older than AEs (39.11). In the 2012 sample there were significantly $\left(\chi^{2}(1)=4.005\right.$, $p=.045)$ more men in AEs (73.9\%) than in SIEs (60.5\%). In both samples AEs worked more often in Finnish and private employer organization than SIEs. In the 2004 sample respondents were asked about the position in the organization during expatriation. The positions differed between AEs and SIEs $\left(\chi^{2}(3)=17.892, \mathrm{p}<.001\right)$ since there were more AEs $(32.7 \%)$ in management than SIEs (14.7\%) and also more AEs (24.0\%) than SIEs (15.7\%) in the upper middle management. About a quarter of AEs and SIEs held a high management status. Twice as many SIEs (42.2\%) than AEs (19.2\%) were in the expert/ officer position.

\section{INSERT HERE}

Table 1 Demographic information of the 2004 and 2012 samples

\footnotetext{
1 Our research, although longitudinal, is not a panel survey. It is a repeated cross-sectional design in which longitudinal data is collected "on the same set of variables for (and perhaps at) two or more periods to include non-identical but comparable cases in each period" (Menard, 2000: 2-3).
} 


\section{Measures}

In order to classify expatriates as AEs or SIEs the respondents were asked whether they had been sent abroad by their employer or had sought a job abroad on their own initiative. For career capital we used the scales from Jokinen, Brewster \& Suutari, (2008). All subdimensions were measured with multiple items on a seven-point Likert-scale, ranging from (1) 'did not improve/ increase at all' to (7) 'improved/ increased very much'. The knowing how (Table 2) scale was measured with 18 items in seven sub-dimensions: task knowledge (3 items), social judgement skills (2), cognitive ability (2), social skills (2), organization knowledge (3), business knowledge (2) and people knowledge (4). The knowing whom (Table 3) scale was measured with four items and the knowing why (Table 4) scale with six items in two sub-dimensions: self-awareness (3) and personal development (3).

\section{INSERT HERE}

Table 2 Knowing how items

Table 3 Knowing whom items

Table 4 Knowing why items

Prior to analysis, the measurements of career capital were validated with confirmatory factor analysis (CFA) using the Mplus 6.12 statistical package (Muthén \& Muthén, 1998-2010) and robust (Satorra-Bentler, 2001) maximum likelihood estimation. The measurement model was examined with only the 2012 sample because the latent variable covariance matrix was not positively definite in the 2004 sample, probably because of sample composition and therefore it was not possible to estimate a multi-group measurement model. The model fit for the measurement model was adequate (Satorra-Bentler scaled $\chi^{2}(338)=493.442$, scaling correction factor $=1.201, p<.001 ;$ SRMR $=.065$, RMSEA $=.050$ (90\% CI: .040-.059); CFI $=$ 
$.918 ; \mathrm{TLI}=.908 ; \mathrm{AIC}=15042.832 ; \mathrm{BIC}=15351.466)$ when referring to the standard cut off values (non-significant $\chi 2$-test, RMSEA $<.06$, SRMR $<.08$, CFI and TLI $>.95 / 90$ indicating a good/ adequate fit. The model fit lower AIC and BIC values has a better fit to the data (e.g., Hu and Bentler, 1999). Standardized factor loadings varied between .528 and .996.

Alternative factor models were also tested. A factor model without sub-dimension structure in knowing how and knowing why (Satorra-Bentler scaled $\chi^{2}(347)=773.615$, scaling correction factor $=1.206, p<.001 ; \Delta \chi^{2}(9)=244.197, p<.001$, SRMR $=.076 ;$ RMSEA $=.082$ (90\% CI: .074-.089); CFI = 775.; TLI = .755; $\mathrm{AIC}=15365.260 ; \mathrm{BIC}=15644.959)$ had inferior fit to the data than the suggested multidimensional measurement model. Also the unidimensional model of career capital (Satorra-Bentler scaled $\chi^{2}(350)=875.291$, scaling correction factor $=1.212, p<.001 ; \Delta \chi^{2}(12)=307.674, p<.001 ; \operatorname{SRMR}=.081 ; \mathrm{RMSEA}=.090$ $(90 \%$ CI: .083-.098); CFI $=.723 ; \mathrm{TLI}=.701 ; \mathrm{AIC}=15756.802 ; \mathrm{BIC}=15490.754)$, where all items loaded only one factor, had a weaker fit than the multidimensional model.

\section{INSERT HERE}

Table 5 Means, standard deviations, Cronbach's alphas and correlations of study variables

The correlations of the career capital scales (Table 5) indicate that there is discriminant validity between the three dimensions of career capital. The inter-correlations between knowing how, knowing whom and knowing why varied between .519 and .726 indicating that these are distinct but inter-related concepts. Reliabilities of the scales were measured with Cronbach's alpha and are acceptable $(\alpha=.698-.909)$.

After the validation of career capital scales the hypotheses of the study were examined with the analysis of variance (ANOVA) controlling the effects of gender and age. Only population level comparisons between 2004 and 2012 were made in this study. 


\section{Findings}

All hypotheses regarding the differences between AEs and SIEs (H1a, H1b and H1c) gained full or partial support from the data (Table 6) meaning that AEs valued career capital more than SIEs. The analyses revealed that there were no significant differences between AEs and SIEs regarding the knowing how career capital scale, although there were significant differences in two sub-dimensions: AEs reported more organizational knowledge than SIEs for both $2004(+0.62, \mathrm{p}<.001)$ and $2012(+0.46, \mathrm{p}=.005)$ and more knowledge of people in $2012(+0.35, \mathrm{p}=0.025)$. Only one knowing how sub-item, knowledge of business, was valued lower than four on a one to seven scale. There were significant differences between SIEs and AEs in terms of their overall knowing whom capital acquisition with AEs gaining more social capital than SIEs in both samples: $2004(+0.48, \mathrm{p}=.002)$ and $2012(+0.32, \mathrm{p}=.009)$. AEs also gained more knowing why than SIEs in the 2012 sample $(+0.34, \mathrm{p}=.006)$. Both AE and SIE participants evaluated an overall increase in their career capital after the expatriate experience.

\section{INSERT HERE}

\section{Table 6 Development of career capital: AEs vs. SEs (marginal means and significance)}

The data suggests that expatriates value the development of career capital more over the long term than the short term for AEs and to some extent, for SIEs. Examining the differences in the 2004 and 2012 samples revealed that AEs valued the overall knowing how $(+0.32$, $\mathrm{p}=.003$ ) significantly more eight years later than they did in 2004. AEs reported significantly higher means for knowing whom $(+0.45, \mathrm{p}<.001)$ and knowing why $(+0.29, \mathrm{p}=.004)$ eight years later. However, SIEs reported significantly more career capital in 2012 than 2004 but only for some aspects of knowing how and knowing whom $(+0.61, \mathrm{p}=.002)$ indicated to be 
higher in the long term than in the short term. These results offer full (for AEs) and partial (for SIEs) support for the hypotheses H2a, H2b and H2c.

\section{Discussion}

Long term research into expatriate populations remains unusual. While global mobility of AE populations has been extensively studied, it is only more recently that research into SIEs has developed (Dorsch et al., 2013). A picture of differences between AEs and SIEs has emerged in the last few years but systematic comparisons of the two populations are relatively rare. Almost all studies have worked with populations that included, if not focused on, recent returners from foreign sojourns. No research has, to our knowledge, explored long term intelligent career considerations contrasting AEs and SIEs.

The findings show that knowing how career capital has substantially increased as a result of the foreign sojourn both for AEs and SIEs. In all areas, with the exception of knowledge of business, increases were above the mid-point of the scale. This shows strong similarities with the insights reported in Jokinen, Brewster \& Suutari, (2008) which indicated no significant differences between the knowing how acquisition of AEs and SIEs. Our evidence also indicates that former expatriates see highly positive career capital effects with respect to knowing whom and knowing why, confirming the broad argument in the literature that expatriates gain more personal awareness and understanding as well as social networks from working abroad (Caligiuri and Lazarova, 2002).

\section{Differences between AEs and SIEs in Perceived Career Capital Acquisition}

AEs show significantly greater increases in knowing whom and knowing why than SIEs. The difference of the knowing whom effect between AEs and SIEs may be partly related to the 
more senior positions that AEs had whilst abroad (Peltokorpi \& Froese, 2009; Suutari \& Brewster, 2000) and the fact that they tended, contrary to SIEs who changed employers and sectors more frequently, to remain in the same organization. They consequently confronted and interacted with similar peer networks whereas SIEs may not have been able to build on their previous networks.

Since SIEs had greater initiative in making and implementing the decision to move to another country, they had proactively reflected on and actively thought about their motivation, their interests and their reasons to move abroad. This was not a step taken lightly. Moving abroad may come as a shock to many AEs who had little time to prepare for the move and had less say in the location choice, so the demands on their emotional and cognitive adjustment (Haslberger \& Brewster, 2009) were higher, with associated gains in knowing why. Our data show that AEs on average work for bigger organizations than SIEs do and larger organizations often have an international HRM department that provides support to expatriates. AEs may thus be more passive than SIEs in the preparation for their foreign assignment, relying on their employer to help them. Pate and Scullion (2010) note that AEs from organizations that provided them with the most support, and largest compensation packages, whilst abroad were also the least satisfied and had the most unrealistic expectations from the organization. Thus arriving and settling into a new country might mean 'facing the reality of expatriation' for the AEs, triggering conditions for self-introspecting, significant reassessing, understanding awareness of what they (and their family when relevant) want out of life overall and work in particular (Haslberger \& Brewster, 2009; Yao, 2013) - knowing why. Not having the same temporal starting point as SIEs explains partially why AEs are on a more rapid upward 'knowing why' learning curve once abroad.

\section{Time Elements and Dynamic Notions of Career Capital Acquisition}


We have argued above that the perpetually increasing globalization of trade and business stimulates and supports the importance of internationally acquired knowing how and knowing whom (Shaffer et al., 2012) which enhance the individual's success in MNCs and other international organizations (Kraimer, Shaffer \& Bolino, 2009). The results of our study provide support to this argument by showing that respondents assessed their career capital growth as significantly higher than they did eight years earlier. Knowing how and knowing whom remain useful and relevant over a long time period. While we did not measure the quality of social networks and international capabilities, it seems reasonable to suggest that individuals kept these links and skills after their international sojourn. In addition, we suspect that many expatriates have, over time, been able to keep in touch, identify the most useful structural and relational contacts (Burt, Kilduff \& Tasselli, 2013) and use them appropriately for their work and career progress.

After their repatriation former AEs have a high likelihood of exploring the best use of their increased knowing how and knowing whom as well as finding the best fit for their changed knowing why (Dickmann \& Doherty, 2008). Our results point to and highlight at the same time that there is insufficient research concerned with the consequences of the growth of internationally acquired career capital on individual-organizational interactions after repatriation. The process to find a better fit 'at home' for one's internationally acquired capabilities, social connections and clear motivational drivers may question the agreements and ways of communicating and interacting between an employee and an employer that were established before the expatriation. The finding that knowing how and knowing whom capital acquisition is more highly valued eight years after their expatriation has neither been anticipated in the literature nor incorporated in any career capital or international mobility model as far as we know. It adds empirical force to the view of expatriation as a crucial developmental strategy. 
A longitudinal perspective can provide valuable nuances to a variety of conceptualizations of global careers and international mobility, for instance, in relation to the general IC approach (Arthur, Claman \& DeFillippi, 1995; Inkson and Arthur, 2001). In the IC conceptualization the three career capital areas are highly interlinked and mutually reinforcing (Lamb \& Sutherland, 2010). The three ways of knowing are equally important and it is recommended to maximize them (Inkson \& Arthur, 2001). However, issues of time and differences in quantity and quality considerations between different career capital areas are neglected.

Knowing How and Time. Our study shows that AEs perceive their acquisition of the three ways of knowing to be higher after a period of time. They found that they were able to transfer and apply knowing how career capital over the eight years. Maximising knowing how is beneficial for careers (Arthur et al., 1995). In addition, increases in foreign knowledge and experience are undoubtedly also valuable due to the context of increasing globalization.

Knowing Whom and Time. Unlike knowing how, the concept of knowing whom has a limit as to how much networking an individual can do. Repatriates' social capital is affected by the strengths of ties and their centrality of network position (Seibert, Kraimer \& Liden, 2001; Burt, 2005). Over time, repatriates will acquire more understanding of their relational and structural capital and can use better quality networking. Ironically, leaving their employers to work in another organization - as many self-initiated repatriates do - can lead to a larger network, but may not be as useful.

Knowing Why and Time.

For knowing why, 'more' may not be 'better', challenging the maximization recommendation in the IC literature (Inkson \& Arthur, 2001). For instance, the expatriates may become aware that a company career is not the best option for them personally. In such circumstances it may cause problems for the company to retain these expensively developed, internationally 
experienced employees, challenging the transferability maxim implicit in the IC concept (Lamb \& Sutherland, 2010).

In essence, while the IC concept is centred around the individual, context and time are important and should be taken into account. The IC concept would benefit from explicitly integrating time into a more nuanced, context-sensitive model.

\section{Conclusions}

Before drawing conclusions, we need to comment on their generalizability by setting them in context. Our study is part of a larger research programme into business graduates in Finland. Whilst we are confident that our sample is representative of that population we cannot tell whether the findings here would apply to other populations. The Finnish labour market has suffered in recent years and the findings may be different for those from stronger employment markets, and they may be different for those who are not graduates.

Our unusual long term study of expatriates who had worked abroad before 2004 found that overall their foreign sojourn had substantially increased all three areas of their career capital and that company-sponsored AEs gained significantly more knowing how, knowing whom and knowing why capital. Our study shows that the long term effects of international mobility are highly positive and support those authors (Edström and Galbraith, 1977; Stahl, Miller \& Tung, 2002) who argue that a key function of expatriation is developmental. Despite dynamic business developments in the meantime, none of the three career capital areas becomes obsolete, even if individuals then spend a long time in their home country.

In terms of one of our theoretical contributions, the study raises questions about the equivalence of the three kinds of career capital and the recommendation to maximize these (Inkson \& Arthur, 2001; Lamb \& Sutherland, 2010). Knowing why has a strong relational 
and structural quality component (Granovetter, 1974; Burt et al., 2013) which challenges simple maximization ideas. Moreover, it is far from clear that an increase in knowing why is beneficial for the individual, his or her family, the employer or wider society. In fact, knowing why has strong links to the protean career concept (Hall, 1996) with its roots in predominantly individualistic Western societies (Hofstede, Hofstede \& Minkov, 2010) and may have different importance and manifestations in more collectivist societies. This insight begins to challenge some of the original writing on intelligent careers (Inkson and Arthur, 2001) and may lead to a more nuanced discussion of the three career capital areas, their interrelationships and the role of context.

Our key contribution is that we show that a dynamic notion of career capital acquisition and use is needed. The extent and value of foreign acquired skills, knowledge and capabilities as well as social capital was seen as significantly higher in the long term. Respondents in 2012 related their current capabilities and networks strongly to their earlier foreign sojourns. This suggests that repatriates and repeat expatriates build on their different forms of career capital and may consciously choose positions in which they can better use their acquired career capital to the benefits of themselves and their organizations. In addition, repatriates may reflect on the three ways of knowing in different ways over time, especially as the increase in seniority of repatriates over time gives them a greater ability to realize the value of a more global understanding of business and how to use their relational and structural social capital (Reiche, Harzing \& Kraimer, 2009) Overall, another contribution of our study is to urge the further development of models of career capital (DeFillippi and Arthur, 1994; Inkson and Arthur, 2001; Parker, Khapova, \& Arthur, 2009), informing models of global careers (Peiperl and Jonsen, 2007) to more explicitly incorporate aspects of quality and context over time.

\section{Practical Implications}


This is the first study that shows the positive, long term effects of career capital acquisition whilst abroad and it has substantial implications for management practice. It shows that those who went to another country on their own initiative (SIEs) rather than being sent as company assignees (AEs) might already have developed much of their knowing why before going abroad. In turn, their knowing whom and knowing how develop substantially during their life abroad. For this reason organizational resourcing strategies for internationally operating firms that typically include returned AEs should also cover former SIEs. Concerns about such factors as 'international skills and knowledge' or 'cross-border networks' becoming outdated or obsolete seem to be a long way from reality. Nor do former expatriates lose their enhanced social capital or return to a cozy, non-challenging mindset. Awareness of these capabilities and the different sources of them opens up opportunities for recruiters and talent planners.

Beyond external resourcing, our findings have strong implications for career and performance management issues as well as future expatriation decisions. Whatever the mode of acquiring international experience, those who have it are valuable members of the organization's talent pool. Speculatively, we might suggest that this would apply to other forms too, i.e., bi-cultural, migrants, etc. HRM specialists need to ensure that they are aware of the international experience of their entire workforce and develop global talent management programs accordingly.

\section{Acknowledgements}

The authors want to thank the Finnish Business School Graduates' Union for providing access to their members working abroad, first in 2004 and again in 2012. 


\section{References}

Al Ariss, A. \& Syed, J. (2011). Capital mobilization of skilled migrants: A relational perspective. British Journal of Management, 22(2), 286-304.

Andresen, M., Al Ariss, A. \& Walther, M. (Eds.). (2013). Self-Initiated Expatriation: Mastering the Dynamics. New York: Routledge.

Andresen, M., Bergdolt, F., Dickmann, M. \& Magenfeld, J. (2014). Addressing international mobility confusion - Developing definitions and differentiations for self-initiated \& assigned expatriates as well as migrants. International Journal of Human Resource Management, 25(16), 2295-2318.

Arthur, M., Claman, P. \& DeFillippi, R. (1995). Intelligent enterprise, intelligent career. Academy of Management Executive, 9(4), 7-20.

Arthur, M. B. \& Rousseau, D. M. (1996). The Boundaryless Career: A new employment principle for a new organizational era. New York: Oxford University Press.

Bozkurt, O. \& Mohr, T. (2011). Forms of cross border mobility and social capital in multinational enterprises. Human Resource Management Journal, 21(2), 138-155.

Briscoe, J. P. \& Hall, D. T. (2006). The interplay of boundaryless and protean careers: Combinations and implications. Journal of Vocational Behavior, 69(1), 4-18.

Brookfield Global Relocation Survey (2014). Global Mobility Trends: 2014 Survey Report. Brookfield: Woodridge, Illinois, USA.

Burt, R. S. (1997). The contingent value of social capital. Administrative Science Quarterly, 42(2), 339-365.

Burt, R. S. (2005). Brokerage and closure: An introduction to social capital. Oxford: Oxford University Press.

Burt, R. S., Kilduff, M. \& Tasselli, S. (2013). Social network analysis: Foundations and frontiers on advantage. Annual Review of Psychology, 64, 527-547. 
Caligiuri, P. \& Lazarova, M. (2002). A model for the influence of social interaction and social support on female expatriates' cross-cultural adjustment. International Journal of Human Resource Management, 13(5), 761-772.

Carr, S. C., Inkson, K. \& Thorn, K. (2005). From global careers to talent flow: Reinterpreting 'brain drain'. Journal of World Business, 40(4), 386-398.

Casper, S. \& Murray, F. (2005). Careers and clusters: analyzing the career network dynamic of biotechnology clusters. Journal of Engineering and Technology Management, 22(1), $51-74$.

Cerdin, J.-L. (2013). Motivation of self-initiated expatriates. In M. Andresen, A. Al Ariss, M. Walther \& K. Wolff (Eds.), Self-initiated expatriation: mastering the dynamics (pp. 5974). London: Routledge.

Cerdin, J.-L. \& Selmer, J. (2014). Who is a self-initiated expatriate? Towards conceptual clarity of a common notion. International Journal of Human Resource Management, 25(9), 1281-1301.

Collings, D., Scullion, H. \& Morley, M. (2007). Changing patterns of global staffing in the multinational enterprise: Challenges to the conventional expatriate assignment and emerging alternatives. Journal of World Business, 42(2): 198-213.

D'Argembeau, A. \& Van der Linden, M. (2008). Remembering pride and shame: Selfenhancement and the phenomenology of autobiographical memory. Memory, 16(5), $538-547$.

DeFillippi, R. \& Arthur, M. (1994). The boundaryless career: a competency-based perspective. Journal of Organizational Behavior, 15(3), 307-324.

Dickmann, M. (2014). Key Trends in Global Mobility, RES Forum, UniGroup Relocation Network and Equus Software, 102 pages, London: RES Forum.

Dickmann, M. and Baruch, Y. (2011). Global Careers, London: Routledge. 
Dickmann, M. \& Doherty, N. (2008). Exploring the Career Capital Impact of International Assignments within Distinct Organizational Contexts. British Journal of Management, 19(2), 145-161.

Dickmann, M., \& Harris, H. (2005). Developing career capital for global careers: The role of international assignments. Journal of World Business, 40(4), 399-408.

Dobbins, G.H., Farh, H.L. \& Werbel, J. D. (1993). The influence of self-monitoring and inflation of grade-point averages for research purposes. Journal of Applied Social Psychology, 23(4), 321-334.

Doherty, N. (2013). Understanding the self-initiated expatriate: A review and directions for future research. International Journal of Management Reviews, 15(4): 447-469.

Doherty, N. \& Dickmann, M. (2012). Measuring the return on investment in international assignments: an action research approach. International Journal of Human Resource Management, 23(16), 3434-3454.

Doherty, N. \& Dickmann, M. (2013). Self-initiated expatriation: Drivers, employment experience and career outcomes. In M. Andresen, A. Al Ariss, M. Walther, \& K. Wolff (Eds.), Self-initiated expatriation: mastering the dynamics (pp. 122-142). London: Routledge.

Doherty, N., Dickmann, M. \& Mills, T. (2011). Exploring the motives of company-backed and self-initiated expatriates. International Journal of Human Resource Management, 22(3), 595-611.

Dorsch, M., Suutari, V. \& Brewster, C. (2013). Research on Self-Initiated Expatriation: history and future directions. In M. Andresen, A. Al Ariss, M. Walther \& K. Wolff (Eds.), Self-initiated expatriation: mastering the dynamics (pp. 42-56) London: Routledge. 
Dowling, P., Festing, M. \& Engle, A. D. (2008). International Human Resource Management, (5 ${ }^{\text {th }}$ ed.). London: Thomson Learning.

Edström, A. \& Galbraith, J. R. (1977). Transfer of managers as a coordination and control strategy in multinational organizations. Administrative Science Quarterly, 22(2), 248263.

Farh, C. I. C., Bartol, K. M., Shapiro, D. L. \& Shin, J. (2010). Networking abroad: A process model of how expatriates form support ties to facilitate adjustment. Academy of Management Review, 35(3), 434-454.

Feldman, D. C. \& Thomas, D. C. (1992). Career management issues facing expatriates. Journal of International Business Studies, 23(2), 271-293.

Gramzow, R. \& Willard, G. (2006). Exaggerating current and past performance: Motivated self-enhancement versus reconstructive memory. Personality and Social Psychology Bulletin, 32(8), 1114-1125.

Granovetter, M. (1974). Getting a job: A study of contracts and careers. Cambridge, MA: Harvard University Press.

Gregersen, H., Morrison, A. \& Black, J. S. (1998). Developing leaders for the global frontier. Sloan Management Review, 40(1), 21-32.

Gunz, H. \& Peiperl, M. (2007). Handbook of Career Studies. London: Sage.

Hall, D. T. (1996). Protean careers of the 21st century. The Academy of Management Executive, 10(4), 8-16.

Harvey, M., Novicevic, M. \& Speier, C. (2000). An innovative global management staffing system: A competency-based perspective. Human Resource Management, 39(4), 381394.

Haslberger, A. \& Brewster, C. (2009). Capital gains: expatriate adjustment and the psychological contract in international careers. Human Resource Management, 48(3), 
379-397.

Hippler, T. (2009). Why do they go? Empirical evidence of employees' motives for seeking or accepting relocation. International Journal of Human Resource Management, 20(6), 1381-1401.

Hippler, T., Brewster, C and Haslberger, A. (2015) The elephant in the room: The role of time in expatriate adjustment International Journal of Human Resource Management 26 (15):1920-1935

Hofstede, G., Hofstede, G.J. \& Minkov, M. (2010) Cultures and Organizations: Software of the Mind. 3rd Edition, New York, McGraw-Hill

Hu, L. T. \& Bentler, P. M. (1999). Cutoff criteria for fit indexes in covariance structure analysis: Conventional criteria versus new alternatives. Structural equation modeling: a multidisciplinary journal, 6(1), 1-55.

Hudson, S. \& Inkson, K. (2006). Volunteer overseas development workers: the hero's adventure and personal transformation. Career Development International, 11(4), 304320.

Ibarra, H. (2003). Working identity. Boston, MA: Harvard Business School Press.

Inkson, K. \& Arthur, M. B. (2001). How to be a successful career capitalist. Organizational Dynamics, 30(1), 48-60.

Jokinen, T. (2010). Development of career capital through international assignments and its transferability to new contexts. Thunderbird International Business Review, 52(4), 325336.

Jokinen, T., Brewster, C. \& Suutari, V. (2008). Career capital during international work experiences: contrasting self-initiated expatriate experiences and assignees expatriation. International Journal of Human Resource Management, 19(6), 979-998. 
Kirk, B. A. \& Sereda, L. (1969). Accuracy of self-reported college grade averages and characteristics of non and discrepant reporters. Educational and Psychological Measurement, 29, 147-155.

Kohonen, E. (2005). Developing global leaders through international assignments: An identity construction perspective. Personnel Review, 34(1), 22-36.

Kraimer, M., Shaffer, M. \& Bolino, M. (2009). The influence of expatriate and repatriate experiences on career advancement and repatriate retention. Human Resource Management, 48(1), 27-48.

Kraimer, M. L., Shaffer, M. A., Harrison, D. A. \& Ren, H. (2012). No place like home? An identity strain perspective on repatriate turnover. Academy of Management Journal, 55(2), 399-420.

Lamb, M. \& Sutherland, M. (2010). The components of career capital for knowledge workers in the global economy. International Journal of Human Resource Management, 21(3), 295-312.

Lazarova, M. B. \& Cerdin, J. L. (2007). Revisiting repatriation concerns: Organizational support versus career and contextual influences. Journal of International Business Studies, 38(3), 404-429.

Lee, C. H. (2005). A study of underemployment among self-initiated expatriates. Journal of World Business, 40(2), 172-187.

Lin, N. (2001). Social capital: A theory of social structure and action. Cambridge: Cambridge University Press.

Mäkelä, K. (2007). Knowledge sharing through expatriate relationships: a social capital perspective. International Studies of Management and Organization, 37(3), 108-125. 
Mäkelä, K., Björkman, I. \& Ehrnrooth, M. (2009). MNC subsidiary staffing architecture: building human and social capital within the organisation. International Journal of Human Resource Management, 20(6), 1273-1290.

Mäkelä, K. \& Brewster, C. (2009) Interunit interaction contexts, interpersonal social capital and the differing levels of knowledge sharing. Human Resource Management, 48(4), 591-613.

McDonnell, A., Lamare, R., Gunnigle, P. \& Lavelle, J. (2010). Developing tomorrow's leaders - evidence of global talent management in Multinational Enterprises. Journal of World Business, 45(2), 150-160.

Näsholm, M. (2014). A comparison of intra- and inter-organizational global careers: repeat expatriates' and international itinerants' subjective experiences. Journal of Global Mobility, 2(2): 183-202.

McNulty, Y. (2013). Are self-initiated expatriates born or made? Exploring the relationship between SE orientation and individual ROI. In V. Vaiman, \& A. Haslberger (Eds.), Talent Management of Self-Initiated Expatriates: A Neglected Source of Global Talent (pp. 30 -58). New York: Palgrave Macmillan.

Mellahi, K. \& Collings, D. G. (2010), The barriers to effective global talent management: The example of corporate elites in MNEs. Journal of World Business, 45(2), 143-149.

Menard, S. (2000). Coefficients of determination for multiple logistic regression analysis. The American Statistician, 54(1), 17-24.

Muthén, L. K., \& Muthén, B. O. (2010). 1998-2010 Mplus user‘s guide.

Nonaka, I. \& Takeuchi, H. (1995). The knowledge-creating company. Oxford: Oxford University Press. 
Oberholster, A., Clarke, R., Bendixen, M. \& Dastoor, B. (2013). Expatriate motivation in religious and humanitarian non-profit organizations. Journal of Global Mobility 1(1), $7-27$.

Parker, P., Khapova, S. \& Arthur, M. (2009). The intelligent career framework as a basis for interdisciplinary inquiry. Journal of Vocational Behavior, 75(3), 291-302.

Pate, J. \& Scullion, H. (2010). The changing nature of the traditional expatriate psychological contract. Employee Relations, 32(1), 56-73.

Peiperl, M. \& Jonsen, K. (2007). Global Careers. In H. Gunz and M. Peiperl (Eds.), Handbook of Career Studies (pp. 350-372). London: Sage.

Peltokorpi, V. (2008). Cross-cultural adjustment of expatriates in Japan. International Journal of Human Resource Management, 19(9), 1588-1606.

Peltokorpi, V. \& Froese, V. (2009). Organizational expatriates and self-initiated expatriates. International Journal of Human Resource Management, 20(5), 1096-1112.

Reiche, B. S., Harzing, A.-W. \& Kraimer, M. L. (2009). The role of international assignees' social capital in creating inter-unit intellectual capital: a cross-level model. Journal of International Business Studies, 40(3), 509-526.

Reiche, B. S., Kraimer, M. L. \& Harzing, A.-W. (2011). Why do international assignees stay? An organizational embeddedness perspective. Journal of International Business Studies, 42(4), 521-544.

Richardson, J. (2006). Self-directed expatriation: family matters. Personnel Review, 35(4), 469-486.

Richardson, J. \& Mallon, M. (2005). Career interrupted? The case of the self-directed expatriate. Journal of World Business, 40(4), 409-420. 
Rodriguez, J. \& Scurry, T. (2014). Career capital development of self-initiated expatriates in Qatar: Cosmopolitan globetrotters, experts and outsiders. The International Journal of Human Resource Management, 25(2): 190-211.

Satorra, A. \& Bentler, P. M. (2001). A scaled difference chi-square test statistic for moment structure analysis. Psychometrika, 66(4), 507-514.

Scullion, H., \& Collings, D. (2010). Global talent management. London: Routledge.

Seibert, S. E., Kraimer, M. L. \& Liden, R. T. (2001). A social capital theory of career success. Academy of Management Journal, 44(2), 316-326.

Shaffer, M. A., Kraimer, M. L., Chen, Y. P. \& Bolino, M. C. (2012). Choices, challenges, and career consequences of global work experiences: A review and future agenda. Journal of Management, 37(4), 1282-1327.

Stahl, G., Chua, C. H., Caligiuri, P., Cerdin, J.-L. \& Taniguchi, M. (2009). Predictors of turnover intentions in learning-driven and demand-driven international assignments: The role of repatriation concerns, satisfaction with company support, and perceived career advancement opportunities. Human Resource Management, 48(1), 89 - 101.

Stahl, G., Miller, E. \& Tung, R. (2002). Toward the boundaryless career: A closer look at the expatriate career concept and the perceived implications of an international assignment. Journal of World Business, 37(3), 216-227.

Sullivan, S. E. \& Arthur, M. (2006). The evolution of the boundaryless career concept: Examining physical and psychological mobility. Journal of Vocational Behavior, 69(1), $19-29$.

Sullivan, S. E. \& Crocitto, M. (2007). The developmental theories: A critical examination of their continuing impact on careers research. In H. Gunz and M. Peiperl (Eds.), Handbook of Career Studies (pp. 283-309). London: Sage. 
Suutari, V. \& Brewster, C. (2000). Making their own way: international experience through self-initiated foreign assignments. Journal of World Business, 35(4), 417-436.

Takeuchi, R., Tesluk, P. E., Yun, S. \& Lepak, D. P. (2005). An integrative view of international experience. The Academy of Management Journal, 48(1), 85-100.

Tharenou, P. (2001). Going up? Do traits and informal social processes predict advancing in management? Academy of Management Journal, 44(5): 1005-17.

Tharenou, P. (2003). The initial development of receptivity to working abroad: self-initiated international work opportunities in young graduate employees. Journal of Occupational and Organizational Psychology, 76(4), 489-515.

Tharenou, P. (2010). Women's self-initiated expatriation as a career option and its ethical issues. Journal of Business Ethics, 95(1), 73-88.

Tharenou, P. \& Caulfield, N. (2010). Will I stay or will I go? Explaining repatriation by selfinitiated expatriates. Academy of Management Journal, 53(5), 1009-1028.

Thorn, K. (2009). The relative importance of motives for international self-initiated mobility. Career Development International, 14(5), 441-464.

Tornikoski, C., Suutari, V. \& Festing, M. (2014). Compensation package of international assignees. In D. G. Collings, G. T. Vood and P. M. Caligiuri (Eds.), The Routledge Companion to International Human Resource Management (pp. 289 - 307). Abingdon: Routledge.

UNCTAD (2012). World Investment Report (2012): Towards a New Generation of Investment Policies, United Nations Conference on Trade and Development, United Nations. New York and Geneva.

Vaiman, V. \& Haslberger, A. (Eds.). (2013). Managing Talent of Self-initiated Expatriates: A neglected source of the global talent flow. New York: Palgrave MacMillan. 
Van Emmerik, H.I.J. \& Euwema, M.C. (2009). The international assignments of peacekeepers: What drives them to seek future expatriation? Human Resource Management, 48(1), 135-151.

Ward, C., Okura, Y., Kennedy, A. \& Kojima, T. (1998). The U-curve on trial: A longitudinal study of psychological and sociocultural adjustment during cross-cultural transition. International Journal of Intercultural Relations, 11(3), 277-291.

Yao, C. (2013). The perceived value of Chinese expatriates' career capital: a symbolic capital perspective, Journal of Global Mobility, 1(2), 187-218. 
Table 1 Demographic information of the 2004 and 2012 samples

\begin{tabular}{|c|c|c|c|c|}
\hline & & All & AEs & SIEs \\
\hline \multirow[t]{2}{*}{ Gender (male) } & 2004 & $148(69.2 \%)$ & $73(70.2 \%)$ & $75(70.1 \%)$ \\
\hline & 2012 & $134(67.7 \%)$ & $82(73.9 \%)$ & $52(60.5 \%)$ \\
\hline \multirow[t]{2}{*}{ Age at 2004} & 2004 & $\mathrm{M}=40.75, \mathrm{SD}=9.45$ & $\mathrm{M}=39.11, \mathrm{SD}=8.67$ & $\mathrm{M}=42.29, \mathrm{SD}=10.00$ \\
\hline & 2012 & $\mathrm{M}=41.97, \mathrm{SD}=9.45$ & $\mathrm{M}=41.98, \mathrm{SD}=9.47$ & $\mathrm{M}=41.81, \mathrm{SD}=9.46$ \\
\hline \multirow[t]{2}{*}{ In a relationship at 2004} & 2004 & - & - & - \\
\hline & 2012 & $163(80.3 \%)$ & $93(82.3 \%)$ & $69(77.5 \%)$ \\
\hline \multirow[t]{2}{*}{ Accompanied by family } & 2004 & - & - & - \\
\hline & 2012 & Yes: 137 (85.1\%) & Yes: $82(89.1 \%)$ & Yes: $54(79.4 \%)$ \\
\hline Finnish employer & 2004 & $95(44.4 \%)$ & $73(70.2)$ & $21(19.6 \%)$ \\
\hline organization & 2012 & $102(51.0 \%)$ & $79(69.9 \%)$ & $23(26.4 \%)$ \\
\hline Private sector employer & 2004 & $157(73.4 \%)$ & $100(96.2 \%)$ & $72(70.6 \%)$ \\
\hline organization & 2012 & $175(86.6 \%)$ & $107(94.7 \%)$ & $68(76.4 \%)$ \\
\hline
\end{tabular}


Table 2 Knowing how items

(1) Task knowledge Knowledge of norms central to your own tasks

(2) Professional/functional knowledge/expertise central to your own tasks

(3) Knowledge of the trends and latest achievements of professional development in your area of responsibility

(4) Social Recognizing the principles of social functioning/interaction

(5) judgement skills Understanding your own role in social organization

(6) Cognitive ability Ability to separate relevant knowledge from irrelevant

(7) Ability to switch the target of concentration quickly

(8) Social Skills Ability to interact socially with people with diverse cultural backgrounds

(9) Ability to make yourself understood in multicultural environments

(10) Organization Understanding the strategic roles of different units of the international organization

(11) knowledge Understanding the components of the organization's international competitive advantage

(12) Knowledge of international management systems of the organization

(13) Business Understanding financial options typical for the business area

(14) knowledge Understanding shareholders' interests

(15) People Understanding factors causing variety in the needs of different people knowledge

(16) Understanding how behavior may reflect different values

(17) Understanding different factors differentiating cultures

Knowledge of general factors guiding human behavior 


\section{Table 3 Knowing whom items}

(1) Ability to link resources and activities internationally

(2) Ability to build inter-organisational networks and teams across boundaries

(3) Ability to build and maintain the external network

(4) Knowledge of people with influential power within organisations 


\section{Table 4 Knowing why items}
(1) Knowing self
I am able to recognize my own strengths and weaknesses, needs and motives
(2)
I understand what other people think about me
(3)
I acknowledge my personal values and beliefs

(4) Personal development I set goals for personal development

(5)

I undertake activities to enhance my skills and competencies

(6)

I want to know more than is required for task accomplishment 
Table 5 Means, standard deviations, Cronbach's alphas and correlations of study variables

\begin{tabular}{|c|c|c|c|c|c|c|c|c|c|c|c|c|c|c|c|c|c|}
\hline & & $\begin{array}{c}\text { No. } \\
\text { items }\end{array}$ & Year & $\mathrm{M}$ & SD & $\alpha$ & 1 & $1 \mathrm{a}$ & $1 \mathrm{~b}$ & $1 \mathrm{c}$ & $1 \mathrm{~d}$ & $1 \mathrm{e}$ & $1 \mathrm{f}$ & $1 \mathrm{~g}$ & 2 & 3 & $3 a$ \\
\hline \multirow[t]{2}{*}{1} & Knowing how & 18 & 2004 & 4.83 & 0.85 & .909 & - & & & & & & & & & & \\
\hline & & & 2012 & 5.13 & 0.83 & .905 & - & & & & & & & & & & \\
\hline \multirow[t]{2}{*}{$1 \mathrm{a}$} & Task knowledge & 3 & 2004 & 4.89 & 1.04 & .703 & .700 & - & & & & & & & & & \\
\hline & & & 2012 & 4.97 & 1.06 & .767 & .711 & - & & & & & & & & & \\
\hline \multirow[t]{2}{*}{$1 b$} & Social judgement & 2 & 2004 & 4.87 & 1.05 & .810 & .714 & .440 & - & & & & & & & & \\
\hline & skills & & 2012 & 5.24 & 1.13 & .835 & .744 & .473 & - & & & & & & & & \\
\hline \multirow[t]{2}{*}{$1 \mathrm{c}$} & Cognitive ability & 2 & 2004 & 4.88 & 1.22 & .731 & .721 & .360 & .484 & - & & & & & & & \\
\hline & & & 2012 & 5.16 & 1.22 & .742 & .706 & .517 & .560 & - & & & & & & & \\
\hline \multirow[t]{2}{*}{$1 d$} & Social Skills & 2 & 2004 & 5.54 & 0.92 & .742 & .600 & .351 & .485 & .372 & - & & & & & & \\
\hline & & & 2012 & 6.08 & 0.88 & .785 & .711 & .385 & .497 & .500 & - & & & & & & \\
\hline \multirow[t]{2}{*}{$1 \mathrm{e}$} & Organization & 3 & 2004 & 4.78 & 1.34 & .822 & .796 & .512 & .489 & .466 & .332 & - & & & & & \\
\hline & knowledge & & 2012 & 5.00 & 1.21 & .793 & .756 & .339 & .432 & .416 & .523 & - & & & & & \\
\hline \multirow[t]{2}{*}{ 1f } & Business knowledge & 2 & 2004 & 3.81 & 1.60 & .620 & .694 & .380 & .331 & .498 & .261 & .530 & - & & & & \\
\hline & & & 2012 & 3.78 & 1.60 & .737 & .711 & .511 & .397 & .316 & .302 & .552 & - & & & & \\
\hline \multirow[t]{2}{*}{$1 \mathrm{~g}$} & People knowledge & 4 & 2004 & 4.90 & 1.03 & .855 & .832 & .468 & .577 & .586 & .537 .6 & .538 & .447 & - & & & \\
\hline & & & 2012 & 5.46 & 0.93 & .841 & .780 & .397 & .577 & .457 & 30 & .480 & .402 & - & & & \\
\hline \multirow[t]{2}{*}{2} & Knowing whom & 4 & 2004 & 4.84 & 1.13 & .775 & .704 & .474 & .466 & .542 & .385 & .698 & .474 & .520 & - & & \\
\hline & & & 2012 & 5.40 & 0.98 & .763 & .726 & .478 & .494 & .541 & .588 & .603 & .435 & .581 & - & & \\
\hline \multirow[t]{2}{*}{3} & Knowing why & 6 & 2004 & 4.96 & 0.80 & .698 & .646 & .437 & .490 & .575 & .483 & .451 & .364 & .558 & .519 & - & \\
\hline & & & 2012 & 5.18 & 0.88 & .808 & .660 & .531 & .512 & .496 & .487 & .500 & .346 & .510 & .629 & - & \\
\hline \multirow[t]{2}{*}{$3 a$} & Knowing self & 3 & 2004 & 5.12 & 0.93 & .692 & .477 & .251 & .348 & .400 & .315 & .415 & .259 & .433 & .343 & .744 & - \\
\hline & & & 2012 & 5.21 & 0.92 & .637 & .582 & .421 & .492 & .416 & .482 & .452 & .252 & .495 & .551 & .888 & - \\
\hline \multirow[t]{2}{*}{$3 b$} & Personal & 3 & 2004 & 4.80 & 1.10 & .749 & .535 & .423 & .417 & .498 & .437 & .301 & .307 & .443 & .465 & .826 & .237 \\
\hline & development & & 2012 & 5.13 & 1.02 & .770 & .597 & .528 & .430 & .467 & .396 & .441 & .363 & .420 & .573 & .911 & .615 \\
\hline
\end{tabular}

Note. All correlations were significant at level $\mathrm{p}<.001$ 
Table 6 Development of career capital: AEs vs. SEs (marginal means and significance)
a) Task-related skills
b) Social judgment skills
c) Cognitive skills
d) Social skills
e) Organisational knowledge
f) Knowledge of business
g) Knowledge of people

2) Knowing whom career capital scale

3) Knowing why career capital scale
a) Knowing self
b) Personal development

1) Knowing how career capital

\begin{tabular}{lllll} 
Year & AEs & SIEs & P-value & Partial Eta $^{2}$ \\
\hline 2004 & 4.85 & 4.77 & .480 & 0.003 \\
2012 & 5.21 & 5.00 & .099 & 0.015 \\
2004 & 4.84 & 4.95 & .490 & 0.002 \\
2012 & 4.96 & 4.99 & .851 & 0.000 \\
2004 & 4.96 & 4.84 & .408 & 0.003 \\
2012 & 5.33 & 5.16 & .331 & 0.005 \\
2004 & 4.86 & 4.80 & .768 & 0.000 \\
2012 & 5.14 & 5.03 & .566 & 0.002 \\
2004 & 5.50 & 5.63 & .287 & 0.006 \\
2012 & 6.12 & 6.05 & .579 & 0.002 \\
2004 & 5.01 & 4.40 & $.001 * * *$ & 0.053 \\
2012 & 5.22 & 4.70 & $.005 * *$ & 0.043 \\
2004 & 3.86 & 3.59 & .228 & 0.007 \\
2012 & 3.70 & 3.61 & .712 & 0.001 \\
2004 & 4.85 & 4.95 & .487 & 0.002 \\
2012 & 5.62 & 5.30 & $.025 *$ & 0.028 \\
& & & & \\
2004 & 5.06 & 4.57 & $.002 * *$ & 0.048 \\
2012 & 5.55 & 5.17 & $.009 * *$ & 0.038 \\
2004 & 5.03 & 4.94 & .410 & 0.003 \\
2012 & 5.37 & 5.01 & $.006 * *$ & 0.042 \\
2004 & 5.25 & 5.10 & .257 & 0.006 \\
2012 & 5.42 & 5.05 & $.006 * *$ & 0.041 \\
2004 & 4.81 & 4.77 & .795 & 0.000 \\
2012 & 5.30 & 4.97 & $.033 *$ & 0.025 \\
\hline
\end{tabular}

Note. Gender and age are controlled in analyses. The marginal means presents the analysis comparing AEs and SIEs. 